УДК 35.088

DOI https://doi.org/10.32838/TNU-2663-6468/2020.3/16

\title{
Карковська В.Я.
}

Національний університет «Львівська політехніка»

\section{ОЦІНЮВАННЯ ДІЯЛЬНОСТІ ДЕРЖАВНИХ СЛУЖБОВЦІВ У ПРОЦЕСІ ЗАБЕЗПЕЧЕННЯ КАДРОВОЇ БЕЗПЕКИ ОРГАНІВ ДЕРЖАВНОЇ ВЛАДИ}

У статті розглянуто актуальні проблеми оцінювання діяльності державних службовиів y прочесі забезпечення кадрової безпеки органів державної влади. Найбільш дієвим способом, що дає змогу в майбутньому оиінити зміни результуючого показника в процесі проведення забезпечення кадрової безпеки органів державної влади, є побудова факторної моделі. Наведено методику реалізачії моделі, яка дасть змогу органам державної влади вести більш поглиблений аналіз і моніторинг у сфері кадрової безпеки. У разі вдосконалення кадрової безпеки в державній сфері слід усвідомити, шо для досягнення найбільшого ефекту необхідно не тільки виявити проблему і знайти шилях ї̈ вирішення, а також систематизувати та відобразити принцип зміни процесів. Це дасть можливість виявити ті загрози, які повторюються періодично. Тоді є можливість розробити програми протидї загрозам. Зазначено, що побудована модель буде відображати найбільш важливі процеси, а також бути основою в оиінюванні можливих загроз. Для створення моделі, щзо надалі сприятиме ефективній ї̈ реалізаиії, необхідно виконувати певні умови, такі як: дотримання правил $і$ норм службовиями відповідних органів державної влади; високий рівень знань службовців державних органів $і$ висока якість виконуваної ними роботи; врахування всіх важливих чинників впливу. Обтрунтовано застосування в прочесі розроблення факторної моделі такі показники, як: коефіцієнт належного виконання всіх норм і правил у державному органі влади; коефіцієнт дотримання i виконання правил і норм службовием; коефіцієнт дотримання $і$ виконання правил $і$ норм під час проведення перевірки в державному органі влади службовием організації, щзо здійснює перевірку; коефіцієнт безпеки органів державної влади, який охоплює всю статистичну звітність щзодо порушень такого державного органу. Застосування розглянутої факторної моделі дасть змогу кожному підрозділу органів державної влади та організаціям, що здійснюватимуть перевірку їхньої діяльності, проводити ефективний моніторинг. Наявність у моделі досліджуваних факторів вказує на те, щฺо процес контролю досить багатосторонній і в ньому участь бере велика кількість об'єктів і суб'єктів.

Ключові слова: кадрова безпека органів державної влади, побудова факторної моделі, механізм оцінювання діяльності державних службовиів, фактори, коефіиієнт безпеки органів державної влади.

Постановка проблеми. Найбільш дієвим способом, що дає змогу в майбутньому оцінити зміни результуючого показника в процесі забезпечення кадрової безпеки органів державної влади, є побудова факторної моделі. Створення такої моделі дасть змогу органам державної влади вести поглиблений аналіз і моніторинг у сфері кадрової безпеки.

Оцінювання результатів службової діяльності - це перевірка рівня якості виконання державним службовцем поставлених йому завдань та посадових обов'язків на підставі показників результативності та ефективності.

Згідно із ЗУ «Про державну службу» [7] під результативністю слід розуміти рівень досягнення проголошених цілей у відповідності до задекларованих. Своєю чергою під ефективністю слід розуміти співвідношення між витратами на впровадження діяльності та досягнутими результатами.

Також важливим елементом оцінювання державного службовця є ступінь дотримання державним службовцем правил етичної поведінки та вимог законодавства у сфері запобігання корупції.

Результати роботи державного службовця щороку підлягають оцінюванню для визначення якості виконання ним поставлених завдань. Результати оцінювання $є$ підставою для прийняття керівництвом рішення щодо його преміювання та кар'єрного зростання, а також, що не менш важливо, потреби та напрями професійного навчання. Таким чином, можна констатувати, що 


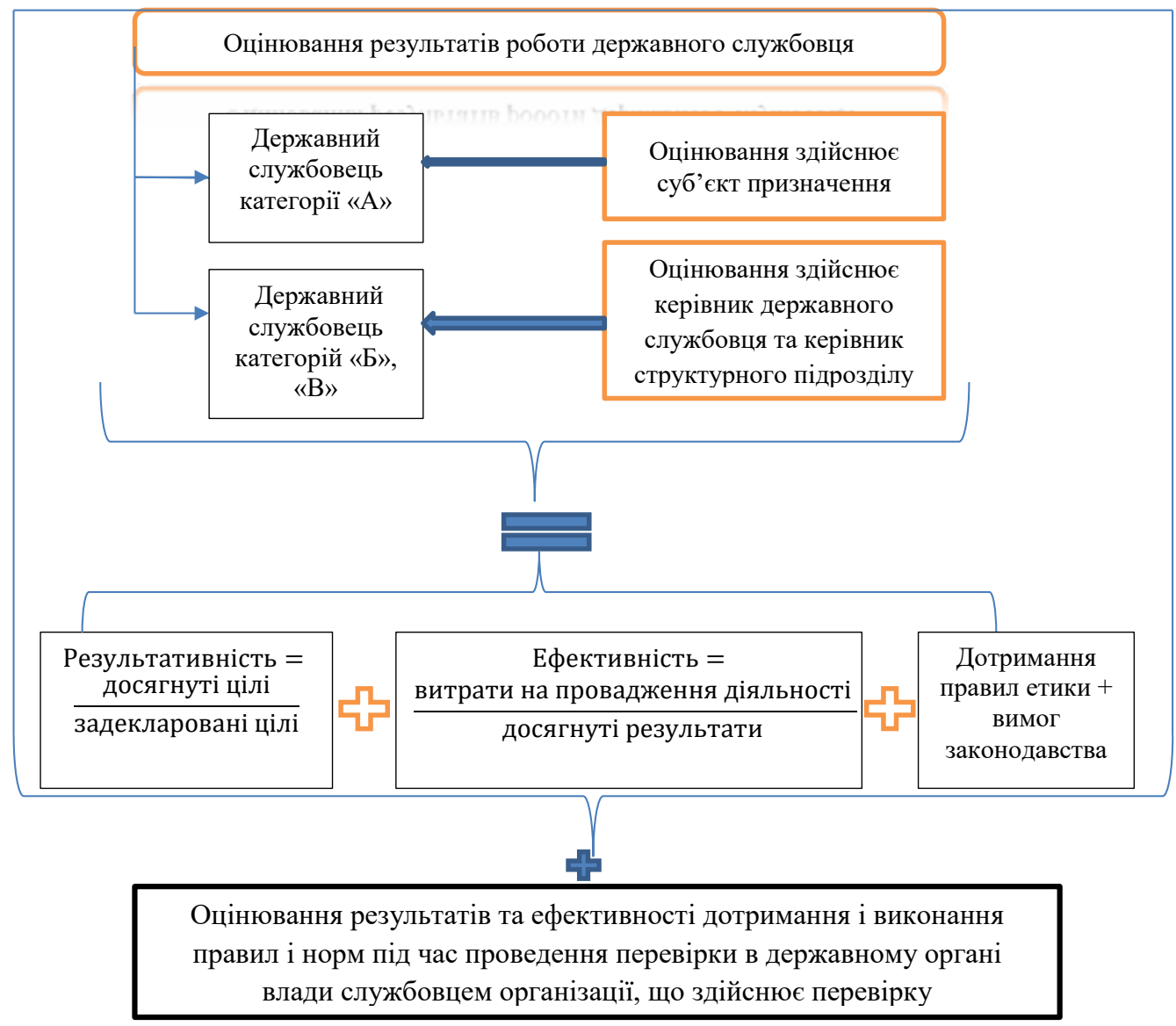

Рис. 1. Механізм оцінювання діяльності державних службовців у процесі забезпечення кадрової безпеки органів державної влади

оцінювання результатів роботи державного службовця є ключовим елементом його мотивування, захисту і аж ніяк мірою виявлення його слабких сторін з подальшими негативними наслідками.

Саме тоді, коли оцінювання ефективності та результативності роботи сприйматиметься крізь призму позитивних тенденцій, можна буде спостерігати зниження рівня загроз кадровій безпеці державних службовців.

Аналіз останніх досліджень і публікацій. На процес забезпечення кадрової безпеки в державній сфері впливає досить багато факторів $[2 ; 6]$. Будь-який процес 3 часом необхідно вдосконалювати.

Під час вдосконалення кадрової безпеки в державній сфері слід усвідомити, що для досягнення найбільшого ефекту необхідно не тільки виявити проблему і знайти шлях її вирішення, а також систематизувати та відобразити принцип зміни процесів [1;3]. Це дасть можливість виявити ті загрози, які повторюються періодично. Тоді є можливість розробити програми протидії загрозам.
Важливим фактором у разі проведення будьякого процесу вдосконалення $\epsilon$ його безперервність. Процес зміни діяльності, що залежить від декількох факторів, у більшості об'єктів або суб'єктів буде завжди мати параболічний графік. Це пояснюється сутністю людської природи (наприклад, властивим людині бажанням отримати більший результат за менші кошти) [8].

Державні органи влади шукають шляхи вдосконалення процесу нагляду та моніторингу, на противагу - службовці шукають усе більш витончені способи, щоб уникнути притягнення до відповідальності за неправомірні дії (при цьому кошти для усунення реально наявної проблеми завжди відсутні) [4; 5].

Постановка завдання. Метою статті $є$ дослідження моделі оцінювання діяльності державних службовців у процесі забезпечення кадрової безпеки органів державної влади.

Виклад основного матеріалу. Перевага моделювання полягає в можливості проводити постійний аналіз зміни як результуючого показника кадрової безпеки, так і внутрішніх чинників, від 
яких вона залежить. Завдяки правильно побудованій моделі з'являється можливість не тільки знайти причину виникнення проблеми, а й 3 огляду на взаємозв'язок факторів виявити спосіб вирішення проблеми.

Варто зазначити, що побудована модель буде відображати найбільш важливі процеси, а також бути основою в оцінюванні можливих загроз. Для створення моделі, що надалі сприятиме ефективній іiі реалізації, необхідно виконувати певні умови, такі як:

- дотримання правил і норм службовцями відповідних органів державної влади;

- високий рівень знань службовців державних органів і висока якість виконуваної ними роботи;

- врахування всіх важливих чинників впливу.

Отже, факторну модель можна відобразити таким чином:

$$
Y_{k b}=X_{1} \times X_{2} \times X_{3},
$$

де $Y_{k b}$ - це коефіцієнт належного виконання всіх норм і правил у державному органі влади. Чим вищий коефіцієнт, тим вищий рівень відсутності порушення в державному органі влади;

$X_{1}$ - коефіцієнт дотримання і виконання правил і норм службовцем;

$X_{2}$ - коефіцієнт дотримання і виконання правил і норм під час проведення перевірки в державному органі влади службовцем організації, що здійснює перевірку;

$X_{3}$ - коефіцієнт безпеки органів державної влади, який охоплює всю статистичну звітність щодо порушень такого державного органу.

Розглянута факторна модель належить до типу мультиплікативних моделей. Для подальших досліджень необхідно описати процес і ступінь впливу кожного з факторів на результуючий показник.

Першим фактором $є$ коефіцієнт дотримання і виконання правил і норм окремого підрозділу службовця. Цей коефіцієнт обчислюється шляхом відношення рівня знань $\left(P_{3}\right)$ такого службовця до рівня порушень $\left(P_{n}\right)$, допущених цим службовцем:

$$
X_{1}=P_{3} / P_{n} \text {. }
$$

Рівень знань буде виражений у відсотках і розраховується залежно від результатів щорічного тестування для всіх службовців, яке необхідно проводити в органах державної влади. Найвищий бал $-100 \%$. Нижня допустима межа кількості балів для допуску службовця до роботи $-50 \%$. На основі цього визначатимуться межі для першого коефіцієнта.
Рівень порушень - це відношення кількості порушених службовцем норм і правил (стосовно нормативних документів) до загальної кількості норм і правил, яких службовець мусить дотримуватися на робочому місці. Отже, описаний показник матиме такий вигляд:

$$
P_{n}=\left\{\begin{array}{l}
\frac{\alpha}{\sum_{n=1}^{i} n} \times 100 \%, \text { при } \alpha<\sum_{n=1}^{i} n, \alpha \neq \sum_{n=1}^{i} n . \\
P_{n}=100 \%, \text { при } \alpha \rightarrow \sum_{n=1}^{i} n,
\end{array}\right.
$$

де $\alpha$ - кількість порушених службовцем підрозділу державного органу влади норм і правил; $\sum_{n=1}^{i} n$-загальна кількість норм і правил, зафіксованих документально, які службовець зобов'язаний виконувати; $P_{n}-$ рівень порушень, допущених одним службовцем.

Слід зазначити, що, виходячи 3 цієї формули, обов'язково повинна виконуватися низка зауважень:

- $\alpha<\sum_{n=1}^{i} n-$ ця умова не може бути порушена через те, що службовець не може порушити правил більше, ніж їхня кількість у зазначених нормативних документах;

$$
-\alpha \neq \sum_{n=1}^{i} n-\text { порушення цієї умови призведе до }
$$

абсолютного невиконання всіх норм і правил в особі одного службовця;

- $\alpha \rightarrow \sum_{n=1}^{i} n-$ ситуація несприятлива внаслідок систематичного недотримання прописаних норм і правил службовцем;

$-P_{n} \rightarrow 100 \%$ - у разі невиконання службовцем правил. Чим нижче значення показника, тим вища свідомість і тим вищий рівень відповідальності у окремого службовця.

Другим фактором, що впливає на коефіцієнт належного виконання норм і правил, $є$ коефіцієнт дотримання і виконання правил і норм під час проведення перевірки в державному органі влади службовцем організації, що здійснює перевірку.

Важливість такого коефіцієнта дуже висока. Оскільки від рівня освіченості інспектора і його вміння проводити відповідну діяльність залежить те, наскільки зможуть дозволяти собі окремі підрозділи органів державної влади не дотримуватися правил і норм, зазначених у нормативних документах. Також, що не менш важливе, це дотримання відповідного рівня безпеки проведення такого виду діяльності. 
Обчислити коефіцієнт дотримання і виконання правил і норм під час проведення перевірки в державному органі влади службовцем організації, що здійснює перевірку, можна на основі співвідношення рівня знань $\left(P_{3}\right)$ службовця організації, що здійснює перевірку, та рівня розкриття злочинів $\left(P_{p 3}\right)$, допущених підрозділом державного органу влади:

$$
K_{\partial \theta}=\frac{P_{p 3}}{P_{3}} .
$$

Рівень знань службовців організації, що здійснює перевірку, виражається у відсотковому вимірі і розраховується залежно від результатів щомісячного тестування для всіх службовців, які проводяться в організації, що здійснює перевірку. Слід зазначити, що періодичність тестування у службовців органів державної влади нижча, оскільки для його проведення необхідною умовою $є$ відрив від основної діяльності як мінімум на один день. Крайнім верхнім пороговим значенням під час проведення тестування є $100 \%$ значення, а нижнім пороговим значенням, що допускає службовця до роботи, є 50\% значення.

Рівень розкриття - це відношення кількості невиконаних службовцем підрозділу державного органу влади норм і правил стосовно нормативних документів, до загальної кількості норм і правил, яких службовці повинні дотримуватися у підрозділі державного органу влади. Математично значення цього показника матиме такий вигляд:

$$
P_{p 3}=\left\{\begin{array}{l}
\frac{\beta}{\sum_{n=1}^{i} H \Pi_{n}} \times 100 \%, \text { при } \beta \leq \sum_{n=1}^{i} H \Pi_{n}, \beta \neq \sum_{n=1}^{i} H \Pi_{n} \\
100 \%, \quad \beta \equiv \sum_{n=1}^{i} H \Pi_{n} .
\end{array}\right.
$$

де $\beta$ - кількість невиконаних службовцем підрозділу державного органу влади норм і правил; $\sum_{n=1}^{i} H \Pi_{n}$ - загальна кількість норм і правил $(n=1 \ldots i)$, зафіксованих документально, які службовець підрозділу державного органу влади зобов'язаний виконувати.

Реалізація системи рівнянь передбачає виконання низки таких умов:

$$
\text { - } \beta \leq \sum_{n=1}^{i} H \Pi_{n} \text { - передбачає неможливість пере- }
$$
вищення кількості порушень більше ніж їхня кількість у нормативних документах. Отже, відкидається можливість дублювання порушень;

$$
-\beta \neq \sum_{n=1}^{i} H \Pi_{n}-\text { порушення цієї умови буде свід- }
$$

ченням абсолютного невиконання всіх норм і пра- вил службовцем підрозділу державного органу влади;

- $\beta \rightarrow \sum_{n=1}^{i} H \Pi_{n}-$ свідчить про зростання порушень службовцем підрозділу державного органу влади норм і правил.

У разі невиконання в підрозділі державного органу влади норм і правил $P_{p 3} \rightarrow 100 \%$. Отже, чим нижче значення досліджуваного коефіцієнта, тим краще в підрозділі державного органу влади дотримуються чинного законодавства і тим вищий рівень кадрової безпеки підрозділу.

Третім досліджуваним фактором під час побудови моделі $є$ коефіцієнт безпеки органів державної влади, який охоплює всю статистичну звітність щодо порушень такого державного органу.

Натепер цей показник розрахувати неможливо через відсутність реальних і загальнодоступних статистичних даних щодо порушень органів державної влади. Однак створення відповідної бази даних $є$ можливим.

3 теоретичної точки зору цей показник включатиме низку таких показників:

- кількість порушень під час проведення всіх перевірок за календарний рік $\left(K_{n p}\right)$;

- кількість перевірок конкретного підрозділу державного органу влади за календарний рік $\left(\Pi_{\kappa}\right)$;

- середній відсоток проведеного тестування конкретного підрозділу державного органу влади за календарний рік $(\bar{m})$.

Отже, математично коефіцієнт безпеки органів державної влади, який охоплює всю статистичну звітність щодо порушень такого державного органу $\left(K_{\sigma}\right)$, матиме такий вигляд:

$$
K_{\sigma}=\bar{m} \times \frac{\Pi_{\kappa}}{K_{n p}} .
$$

У зв'язку із відсутністю спеціалізованого підрозділу щодо систематизації статистичної інформації порушень у діяльності органів державної влади досліджувану модель можна застосовувати на практиці без урахування третього показника.

Висновки. Застосування розглянутої факторної моделі дасть змогу кожному підрозділу органів державної влади та організаціям, що проводитимуть перевірку їхньої діяльності, здійснювати ефективний моніторинг. Наявність у моделі досліджуваних факторів вказує на те, що процес контролю досить багатосторонній і в ньому участь бере велика кількість об'єктів і суб'єктів. Подальше дослідження щодо показника безпеки вкрай важливе, оскільки він не тільки допоможе проводити більш глибокий аналіз, але і сприятиме 
підвищенню ефективності роботи підрозділів органів державної влади. Також варто відзначити, що досліджувана факторна модель дасть змогу проводити детальний аналіз у разі виникнення проблем, пов'язаних з кадровою безпекою органів державної влади.

\section{Список літератури:}

1. Yaremko I., Karkovska V. Assessment of Governmental Bodies Officials Activity Results Based on Factor Model Development. Economics, entrepreneurship, management, 2017. Vol. 4. No.1, pp. 83-89.

2. Банчук-Петросова О.В. Теоретичні основи сучасної державної кадрової політики України. Держсавне управління: удосконалення та розвиток, 2013, № 7.

3. Галаз Р.І. Еволюція поняття «кадрова безпека підприємства». Наукові записки Львівського університету бізнесу та права, 2013, № 10, с. 340-343.

4. Іванова К.В. Теоретичні засади формування державної служби України: зміст, форми та методи стратегічного державного управління. 2016.

5. Івануса А.І., Василишин Я.І. Модель проєкту підвищення ефективності кадрової політики в силових структурах. Вісник Львівського державного університету безпеки життєдіяльності, 2014, № 10, с. 94-98.

6. Кобринський В.Ю., Іващенко В.О. Державний контроль у сфері національної безпеки України : монографія. Переяслав-Хмельницький : «Видавництво К С, 2008.

7. Про державну службу : Закон України від 10 грудня 2015 року № 889-VIII. URL: http://zakon4.rada.gov.ua/laws/show/889-19 (дата звернення: 15.02.2019).

8. Рачинський А. Стратегічна роль персоналу органів державної влади у подоланні кризи. Вісник Національної академї державного управління при Президентові України, 2011, № 1. С. 48-56.

\section{Karkovska V.Ya. ASSESSMENT OF THE ACTIVITIES OF CIVIL SERVANTS IN THE PROCESS OF PROVIDING STAFF SECURITY BODIES}

The article deals with the actual problems of evaluating the activity of civil servants in the process of ensuring the personnel security of public authorities. The most effective way of assessing changes in the resultant indicator in the process of ensuring personnel security of public authorities in the future is to build a factor model. The methodology for the implementation of the model, which will allow the authorities to conduct more in-depth analysis and monitoring in the field of personnel security, is presented. When improving personnel security in the public sphere, it should be realized that to achieve the greatest effect, it is necessary not only to identify the problem and find a way to solve it, but also to systematize and reflect the principle of changing processes. This will allow you to identify those threats that are repeated periodically. Then there is an opportunity to develop programs to counter threats. It is stated that the constructed model will reflect the most important processes and also be the basis for assessing possible threats. To create a model that will further facilitate its effective implementation, certain conditions must be met: compliance with the rules and regulations by officials of the relevant public authorities; high level of knowledge of employees of state bodies and high quality of their work; consideration of all important factors of influence. In the process of developing a factor model, such indicators as the coefficient of proper implementation of all rules and rules in the state authority are substantiated; the coefficient of compliance and enforcement of rules and regulations by the employee; the coefficient of compliance and enforcement of rules and norms when conducting a check in a public authority by an employee of the organization conducting the check; a government security factor that covers all statistical reporting of violations of a government agency. The application of the considered factor model will allow each subdivision of public authorities and organizations that will check their activity to carry out effective monitoring. The presence in the model of the investigated factors indicates that the control process is quite multilateral and involved in a large number of objects and entities.

Key words: personnel safety of public authorities, construction of factor model, mechanism of evaluation of civil servants activity, factors, safety factor of public authorities. 